\title{
4. Bede Nairn and Geoffrey Serle: A Fine Partnership, 1973-1987
}

\author{
Christopher Cunneen
}

When the Australian Dictionary of Biography's general editor, Douglas Pike, was felled by a devastating stroke on Remembrance Day 1973, the $A D B$ team was fortunate to have, at 'first drop' (to use a cricketing analogy that Bede Nairn might have appreciated), a veritable Victor Trumper of a historian, able to continue the strong innings that the openers had established. ${ }^{1}$

\section{Nairn: Consolidating the innings}

Noel Bede Nairn (1917-2006) was born on 6 August 1917 at Turill, near Mudgee, NSW, youngest of six children of Robert John (Jack) Nairn and his wife, Rose Ann, née Hopkins. ${ }^{2}$ When the boy was six, the family moved to inner Sydney, where Jack worked as a council watchman and cleaner. Though the Nairns were close to poverty, Bede's mother, Rose, bought a piano and he took music lessons, financed by taking in boarders. He was educated at St John's Poor School, in Kent Street, and then by the Christian Brothers at St Mary's Cathedral School, where he completed the Intermediate Certificate. On leaving school, he worked for the NSW Electoral Office. While studying for matriculation part-time, he worked as a clerk at Sydney Technical College; later he was an evening student at the University of Sydney (BA Hons, 1945; MA, 1955). He married Jean Hayward on 26 January 1943.

In 1948 he taught at Sydney Technical College, Ultimo, and the following year lectured in history at the newly founded NSW University of Technology (now University of New South Wales); in 1956 he became senior lecturer and head of the school of history at the university and, in 1961, associate professor of history. In 1957, on a Rockefeller grant, he and his family went to Balliol College, Oxford, where he researched trade unions in Britain.

\footnotetext{
1 J. A. La Nauze, Chairman, to Members of the $A D B$ Editorial Board (11 September 1975), box 70, Q31, ANUA, ADBA.

2 For biographical details, see Chris Cunneen, 'The ADB's Second General Editor', in Australian Dictionary of Biography, vol. 17 (Carlton, Vic.: Melbourne University Press, 2007), pp. xiii-xiv. 'A Big Fella in His Field', Sydney Morning Herald (5 May 2006). Geoff Serle, 'Bede Nairn: His Life and Work', in Bede Nairn and Labor History (Sydney: Pluto Press, 1991), pp. 3-10. I am grateful for the help of Martha Campbell, Sally O'Neill, Suzanne Edgar, Helga Griffin and John Thompson in writing this account.
} 
The ADB's Story

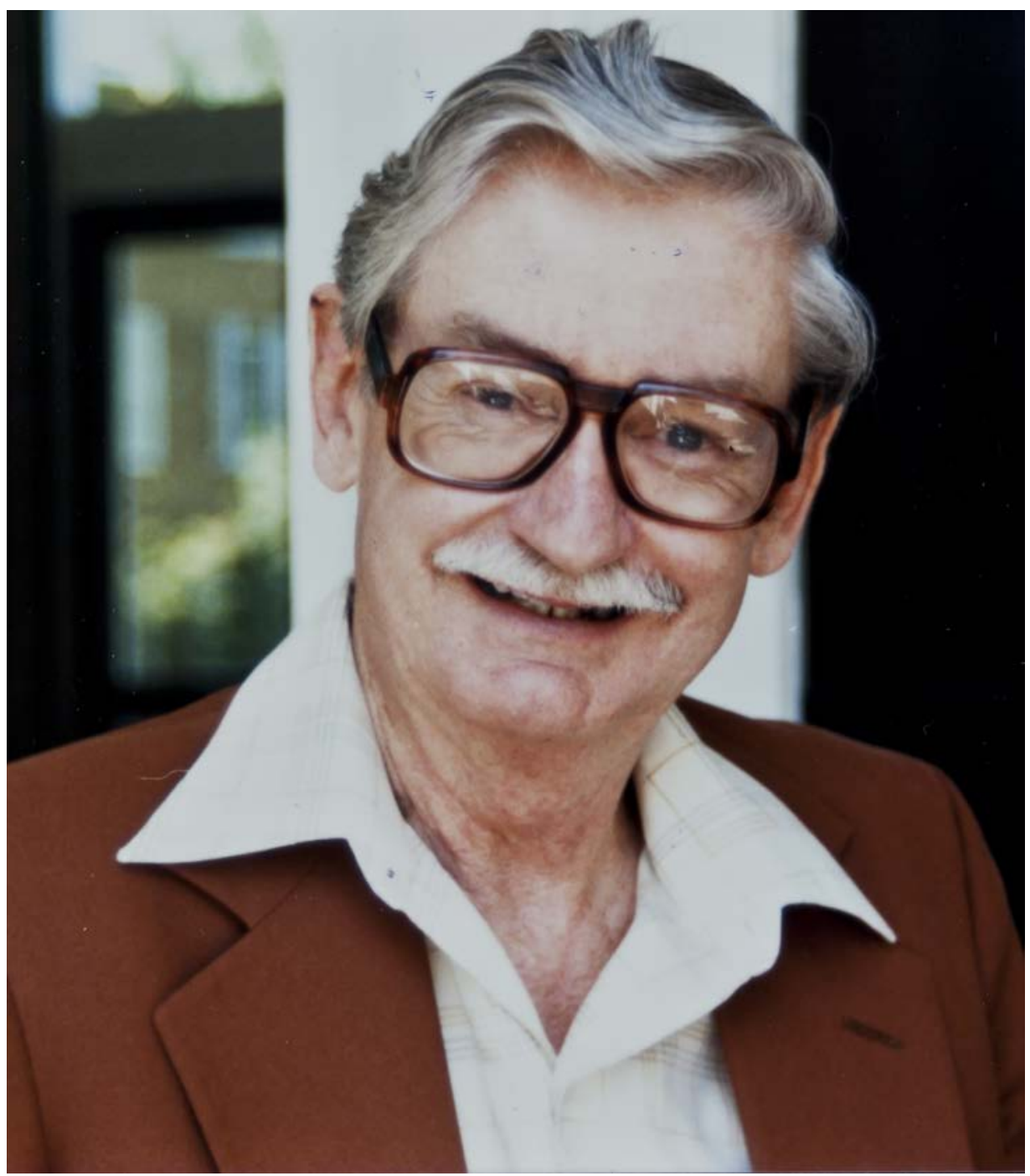

\section{Bede Nairn, 1985}

By courtesy of Sue Edgar 


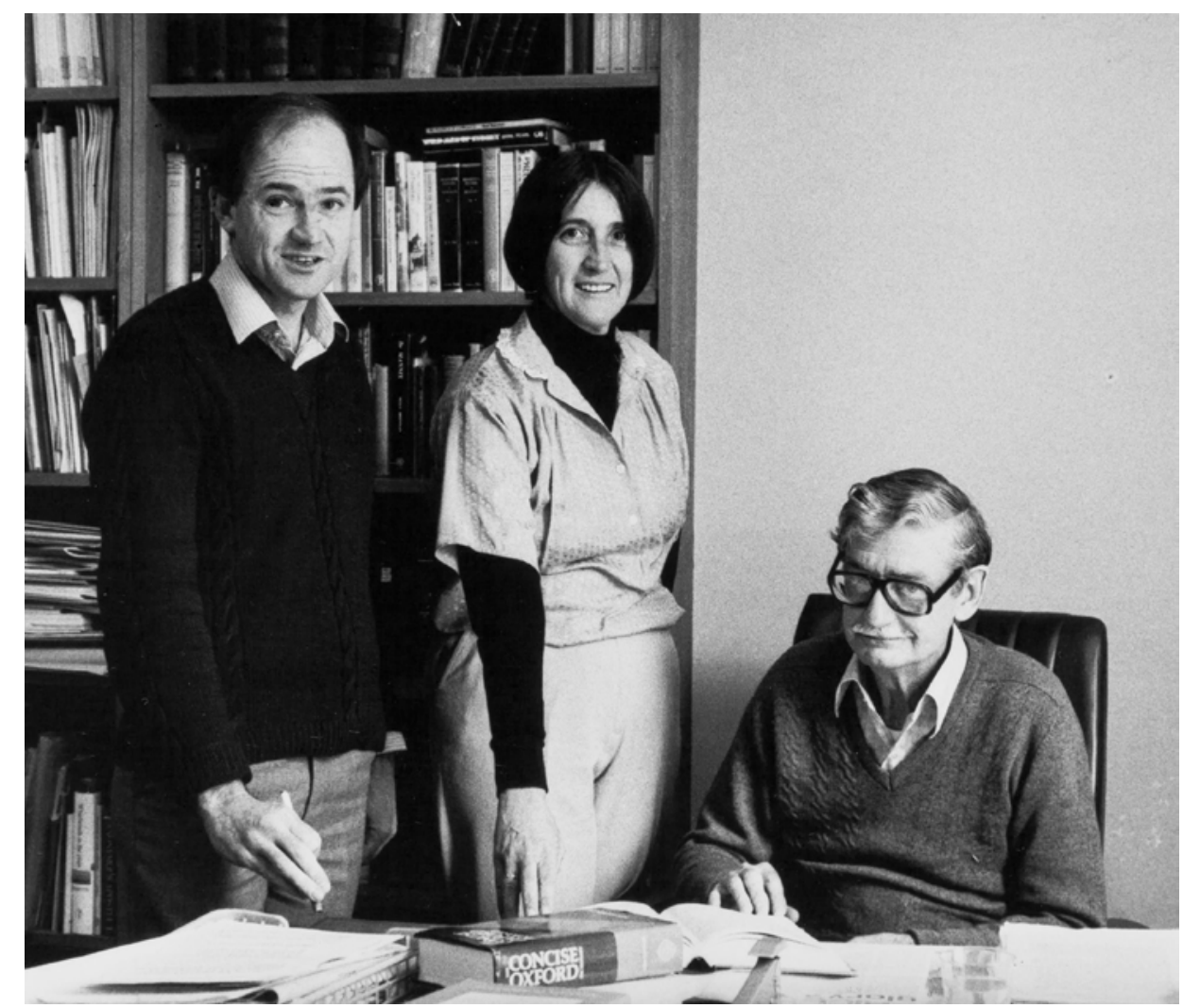

ADB staff, Chris Cunneen, Marion Consandine and Bede Nairn, 1983

ANU Archives, ANUA226-689

Nairn became chairman of the $A D B$ 's NSW Working Party in 1962, and guided the committee through the latter part of the ructions caused by Malcolm Ellis. He quickly became an essential element in the team of volunteers supporting the work of Pike in the early volumes of the dictionary. Nairn was not, however, an early member of the National Committee that established the $A D B$, though in 1965 he did act on that committee as a replacement for the departed John Salmon. Nor was he a member of the Editorial Board that governed the project prior to the publication of Volumes 1 and 2 in 1966-67. Indeed, he did not contribute any entries to Volume 1 and only two to Volume 2; it is significant that those two were on the pastoralist/politician Hannibal Macarthur, and the Catholic Archbishop John Bede Polding. (It is possible that Nairn was actually named after Bede Polding, though not by his parents. His son John has told me that the parents had wanted to baptise him Lloyd George Nairn, but that the officiating priest had refused to allow it.) 
After a sabbatical year at the ANU in Canberra in 1965, the Nairn family moved there permanently in 1966. On the ANU staff, Nairn became deputy to Pike and he now joined the National Committee and the Editorial Board. With Geoffrey Serle and Russel Ward, he was a section editor for Volumes 3-4, covering people who flourished in 1851-90. He continued his membership of the NSW Working Party, but handed the chairmanship to Gordon Richardson, the State librarian of New South Wales, who was in turn succeeded by Russell Doust. In addition to his work on the $A D B$, Nairn took a prominent role in the Australian Society for the Study of Labour History, serving as vice-president and a member of the editorial board of Labour History, and completed his groundbreaking book Civilising Capitalism: The Labor Movement in New South Wales 1870-1900 (1973). ${ }^{3}$ So he was ready, when Pike fell ill, to step in and complete the final stages of work on Volume 5.

At the urging of the then chairman of the Editorial Board, John La Nauze, Nairn agreed to act as general editor for Volume 6. He accomplished this at a difficult time, when the publisher of Melbourne University Press, Peter Ryan, was having one of his obstreperous periods. In response to a demand from MUP that the length of the volume be reduced, Nairn was forced to delete a large number of articles - 30 were removed from the NSW list alone - some of which had already been commissioned and, indeed, written. Still, Volume 6, though slimmer than the others in the series, was a notable continuation of the form and style set by Pike.

Nairn was enormously assisted in his task by the remarkable team of research assistants Pike had assembled. The administrative role of Nan Phillips was notable, and the skilled editing of Martha Campbell, Sally O'Neill, Suzanne Edgar and the late Deirdre Morris was clear to me when I joined the team in 1974. Nairn retained the spare style - notoriously devoid of adjectives - that Pike had established. Indeed, his enthusiasm for abbreviation was even more zealous, perhaps because of the limitations in length of the volume imposed by MUP. Nairn insisted on the use of short verbs, such as 'quit', and he was responsible for persuading Pike to allow staff to be credited for the entries they had written. Staff have described Nairn as 'full of humour, warmth and kindness', which he 'let ... shine out'. Under him, research assistants had much more responsibility for preliminary editing. With support from other research assistants, Edgar drafted a proposal for them to be designated internally as research editors. Nairn supported that change successfully. He was an excellent and involving manager of his team, and his many staff meetings, at which everyone happily discussed at length such weighty issues as whether to hyphenate or not, are well remembered.

3 Bede Nairn, Civilising Capitalism: The Beginnings of the Australian Labor Party (Carlton, Vic.: Melbourne University Press, 1989). Frank Bongiorno, 'Nairn (N) B', in G. Davison, J. Hirst and S. Macintyre (eds), The Oxford Companion to Australian History, rev. edn (Oxford: Oxford University Press, 2001), p. 455. 
Jim Gibbney was another memorable team member inherited by Nairn. He had taken over the role of 'biographical registrar', or gatherer of biographical data. This task has always been a crucial aspect of the $A D B$ work and Gibbney, an amiable and much-loved figure in Canberra, and a habitué of the National Library's Petherick Room 'Club', ${ }^{4}$ helped to gather the thousands of little white cards filled with biographical data. Authors have been grateful to Gibbney's Biographical Register for its help in the writing of $A D B$ entries. At Nairn's urging, Gibbney began, and Ann Smith completed, the useful two-volume Biographical Register, 1788-1939 (1987). ${ }^{5}$

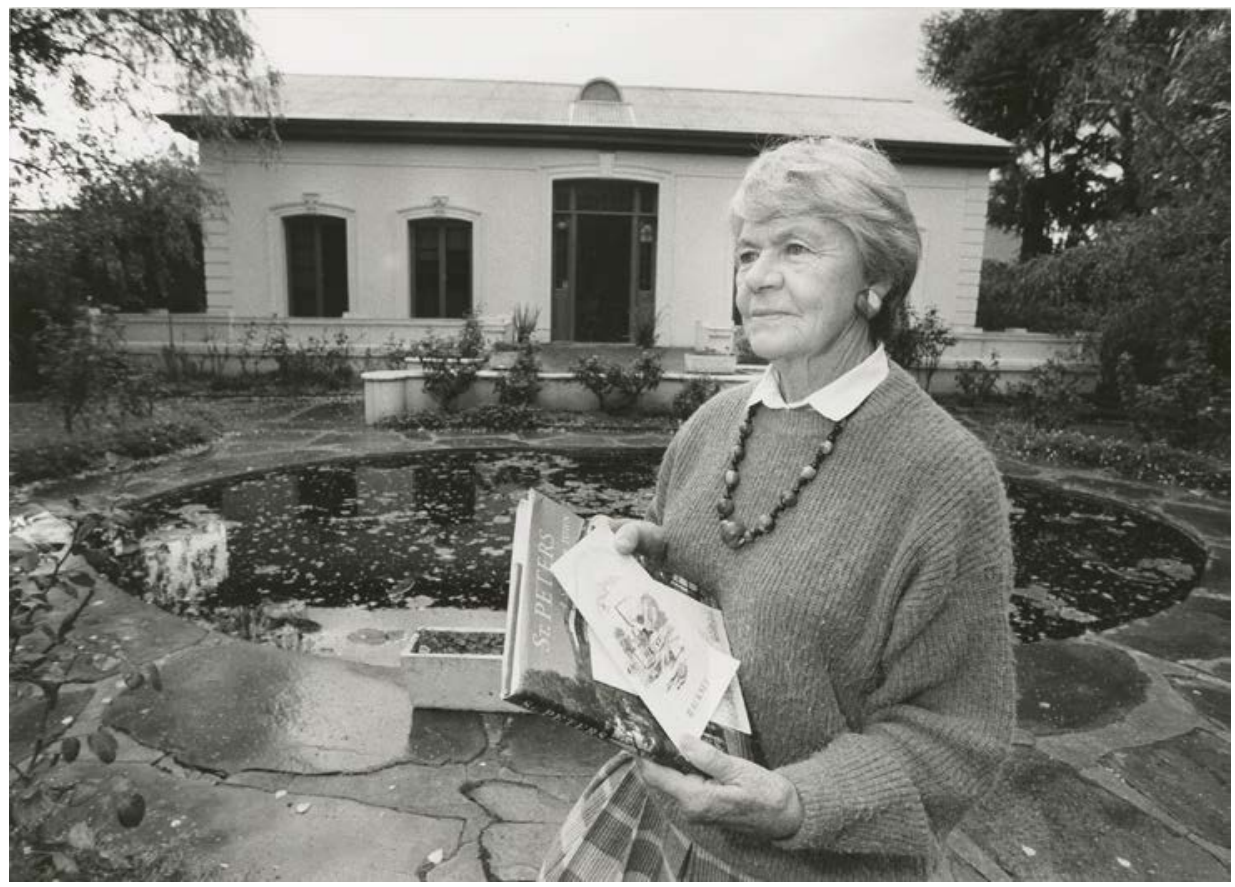

Joyce Gibberd was the $A D B$ 's South Australian research assistant in 1974-2005, a member of that State's working party in 1990-2005 and wrote $21 A D B$ entries. She was awarded an $A D B$ Medal in 2002

\section{$A D B$ archives}

Nairn brought his innate administrative efficiency to the business of gathering certificates of birth, death and marriage (BDM). He and I travelled around Australia, spoke to registrars-general in each State and secured special concessions that enabled the $A D B$ to obtain such information centrally and efficiently. The system of BDM data collection varied from State to State. In

4 Gibbney had the number one Petherick ticket: see Graeme Powell, 'The Readers of "68"', National Library of Australia News, 12, no. 2 (November 2001), pp. 14-16.

5 H. J. Gibbney and Ann G. Smith (comps and eds), A Biographical Register 1788-1939: Notes from the Name Index of the Australian Dictionary of Biography, 2 vols (Canberra: Australian Dictionary of Biography, 1987). 
some States, the registrar's office provided the information as uncertified copies. In the case of Queensland, one registrar-general transcribed by hand the details from the registers. In Sydney, Nairn was given privileged access to the files and he himself transcribed the BDM details. He soon handed that task to me and I continued to do the transcribing of NSW certificates until new privacy and security measures were introduced some 20 years later. The gathering of BDM material in a period of increasing concerns about privacy continues to cause anxiety.

Another task carried out successfully by Nairn, while he worked on Volume 6 , was the reinvigoration of the working parties. On our tours to the various State capitals, Nairn and I met with key historians for advice on the best way to proceed. In some cases the working parties had more or less withered and Nairn started over from scratch. In particular, I remember with affection the support and friendship of Denis Murphy in Queensland, assisted by Paul Wilson and the splendid Spencer Routh. In South Australia, John Playford assembled a new team, assisted by Harold Finnis, John Love, Peter Howell and others. In other States we met stalwarts such as Geoffrey Bolton (in Perth) and Michael Roe (in Hobart), both of whom set up committees crucial in the whole $A D B$ enterprise, which continue to be so. The Armed Services Working Party, steered by Bob O'Neill, had been established under Pike, and was from the start a splendid and efficient committee, full of engaging and memorable characters such as Alec Hill, Colonel Frank Brown and the inimitable Brigadier 'Bunny' Austin.

Nairn also formalised the previously informal system of interstate research assistance. When Pike had wanted a reference checked in Perth, Adelaide or Hobart, he would write to his friends, and ask them to help! Two of these were Wendy Birman, in Perth, and Joyce Gibberd, in Adelaide. On our travels, Nairn and I met these friends, and they agreed to continue as interstate research assistants. Both are worthy recipients of the $A D B$ Medal, initiated by John Ritchie.

Among the several Sydney researchers who helped me in the time of Nairn and Serle were Ruth Frappell and Mike Bosworth. Interstate and overseas research assistants who gave generously of their time and commitment during the Nairn-Serle era included Jennifer Harrison and Anne Rand (both recipients of $A D B$ Medals), Barbara Dale, Naomi Turner, Susan Hogan, Noeline Hall, Betty Crouchley, Mimi Colligan, Geoff Browne, Beth McLeod, Gillian Winter and Leonie Glen. The $A D B$ owes them a great debt of gratitude. 
4. Bede Nairn and Geoffrey Serle: A Fine Partnership, 1973-1987

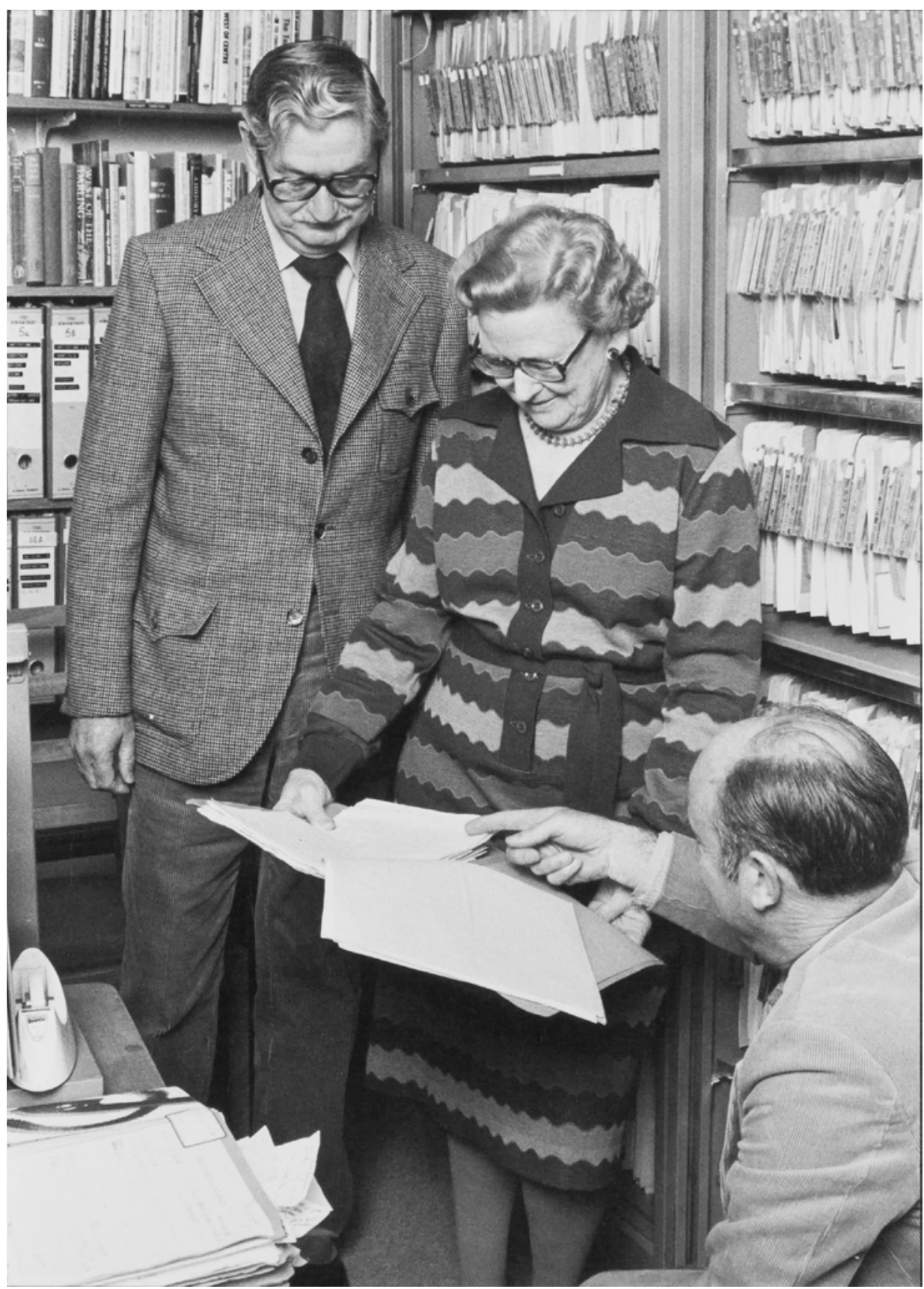

Bede Nairn, Nan Phillips and Geoffrey Serle in the $A D B$ 's library

ANU Archives, ANUA226-680 


\section{A fine partnership}

Nairn was the sole general editor for Volume 6 . When the position of general editor was eventually advertised, the Editorial Board was unable to find a suitable candidate. Neither Nairn nor Serle had applied, knowing that the position was an all-absorbing job. ${ }^{6}$ Then Serle had the idea that he and Nairn should apply jointly. Nairn agreed, as did the board (though La Nauze needed to be persuaded by Serle), ${ }^{7}$ and in 1975 the two were appointed as joint general editors. ${ }^{8}$ The arrangement agreed upon was that Serle would visit Canberra for only two or three days a fortnight. Serle later joked that '[i]t wasn't a bad idea to appoint a Sydney Catholic and a Melbourne Protestant: it surely would have been much worse the other way around'. ${ }^{9}$

Nairn did not commit his assessment of Geoff Serle to paper, but in a rare interview granted to John Thompson, he was at pains to draw out the

differences between the two collaborators - the differences that came from their almost diametrically opposed intellectual and cultural backgrounds (Melbourne versus Sydney; Catholic versus Protestant; [Serle's] privilege [but not of money] as opposed to Nairn's simpler, working-class origins; Nairn's love of the turf against [Serle's] complete indifference/antipathy - Nairn was puzzled by this). ${ }^{10}$

Although Nairn stressed the differences between the two editors, there were notable similarities. Both were softly spoken family men; both were influenced by, and supporters of, Manning Clark; both were staunch Labor supporters, though neither was particularly radical, and each was criticised by the 'New Left' historians of the 1970s; both were what might now be described as 'blokey', sporty men who enjoyed a beer in mostly male company after work on Tuesday afternoon.

\section{Serle: The stylist}

We are fortunate to have in John Thompson's masterly biography The Patrician and the Bloke (2006) a comprehensive account of Serle's role as a teacher, historian and biographer. Alan Geoffrey Serle (1922-98) was born on 11 March 1922 at Hawthorn, Melbourne, third and last child of Percival Serle, accountant and

\footnotetext{
Minutes, $A D B$ Editorial Board meeting (22 February 1974), box 64, Q31, ADBA, ANUA.

Bede Nairn and Geoffrey Serle to John La Nauze (19 August 1974), box 70, Q31, ADBA, ANUA.

See Serle, 'Bede Nairn'.

Serle, 'Bede Nairn', p. 6.

10 John Thompson to Chris Cunneen, email (24 November 2009).
} 
scholar, and his wife, Dora, née Hake, a skilled artist. Educated at Scotch College and the University of Melbourne, the youngster had some of his middle-class, scholarly smoothness roughened by war service in the ranks in New Guinea where he was seriously wounded. He recovered in Queensland, before resuming his university studies (BA Hons, 1946). Winning a Rhodes Scholarship, he entered University College, Oxford. He graduated DPhil in 1950. He returned to Melbourne University, where he taught Australian history, and then moved to Monash University. In 1955 he married Jessie McDonald.

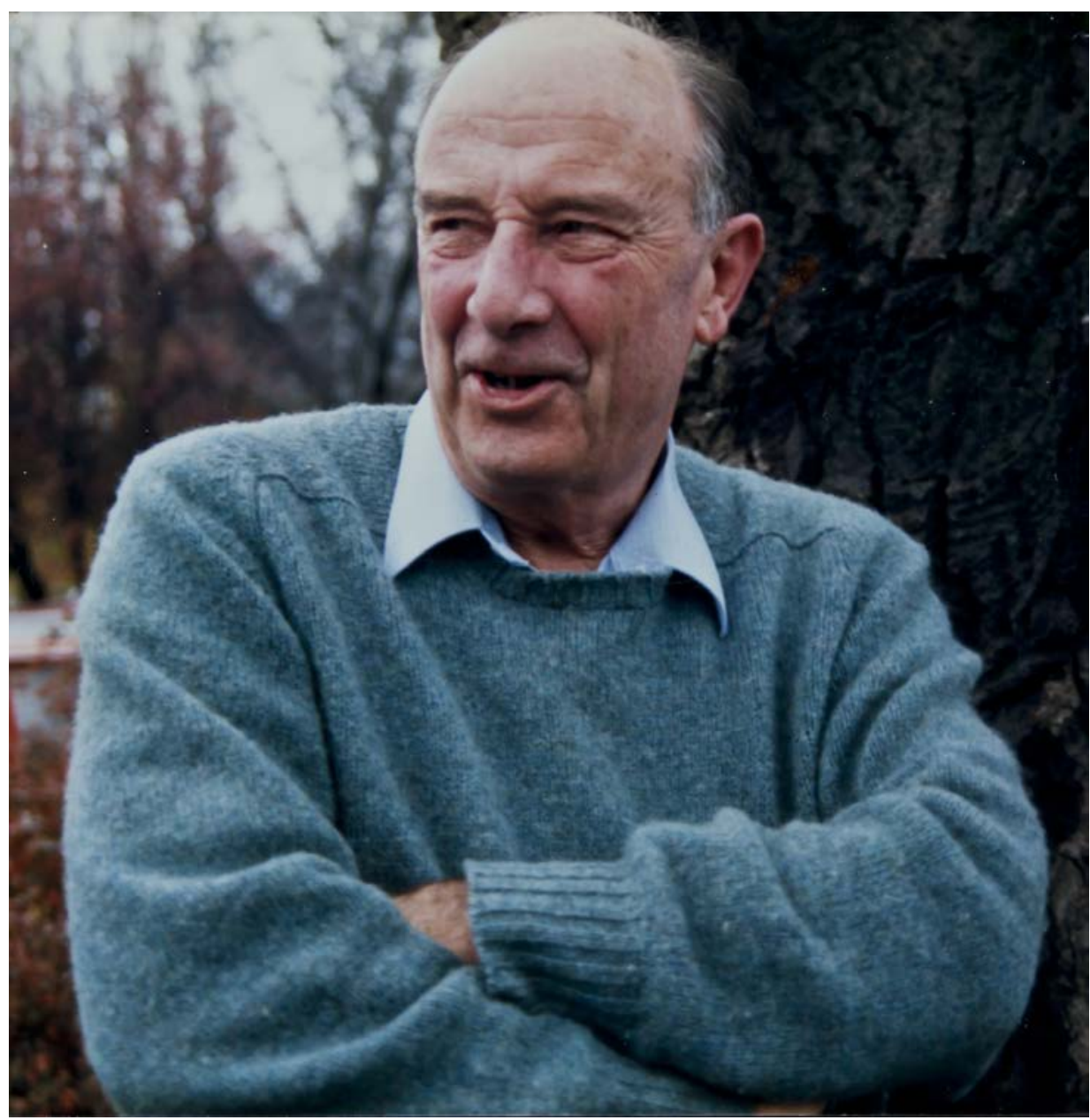

Geoff Serle, 1980s

By courtesy of Sue Edgar 
Serle's two important histories of colonial Victoria, The Golden Age (1963) and The Rush to be Rich (1971), and the pioneering history of Australian culture From Deserts the Prophets Come (1973) ${ }^{11}$ had shown him to be a leading exponent of what Thompson calls a 'new nationalistic approach to the teaching and writing of Australian history'. ${ }^{12}$ Moreover, his father's long and fruitful engagement with Australian biography - notably, as author of the two-volume Dictionary of Australian Biography (1949) - had instilled in him a lifelong interest in biographical research. He was a founding member of the $A D B$ National Committee, and of the Editorial Board. Like Nairn, he was a section editor for Volumes 3-6 (those who flourished in 1851-90).

As joint general editors, Nairn and Serle produced the bulk of Volumes 7-10 that included the men and women who flourished in the half-century from 1891 to 1939 and that covered the period of the depression of the 1890s, the Federation movement, the Boer War, the early years of the Commonwealth, World War I and the Great Depression - in ADB 'lingo' this was Period 3, or P3. The decision to continue to use the floruit principle and devote six volumes to this period and to stop before World War II dated from Pike's general editorship. Nairn, Serle and the Editorial Board confirmed this plan. After Nairn's serious illness in 1982, and retirement in 1984, Serle became the sole general editor for Volume 11. To allow for preparations of lists and authors for a new period, and for Nairn to take overdue sabbatical leave in 1977, there was a delay of three years between publication of Nairn's Volume 6 in 1976 and Volume 7-the first of the jointly edited volumes - in 1979; however, through a sustained period of activity, the following four volumes were published in 1981, 1983, 1986 and 1988. In March 1988 Serle retired.

Neither Serle nor Nairn wrote much in the way of a reflective account of what we might think of as their 'editorial philosophy' for the $A D B$. The prefaces in their volumes were bare, formulaic, half-page explanations of the form and structure of the work. When Serle was forced to produce an information sheet for a Research School of Social Sciences open day in 1981, he sighed, took some paper (and a bottle of red wine) back to the college in the evening and returned next day with his summary, which was incorporated into a blue brochure. Some of his modus operandi might be gleaned from this unlikely source: 'Following the precedents of the British Dictionary of National Biography and the Dictionary of American Biography, nearly twenty countries are engaged in building similar memorials to their "mighty dead"'.

11 Geoffrey Serle, The Golden Age: A History of the Colony of Victoria, 1851-1861 (Melbourne: Melbourne University Press, 1963); The Rush to be Rich: A History of the Colony of Victoria, 1883-1889 (Melbourne: Melbourne University Press, 1971); and From Deserts the Prophets Come: The Creative Spirit in Australia 1788-1972 (Melbourne: Heinemann, 1973).

12 J. R. Thompson, The Patrician and the Bloke (Canberra: Pandanus Books, 2006), p. xxiii. 


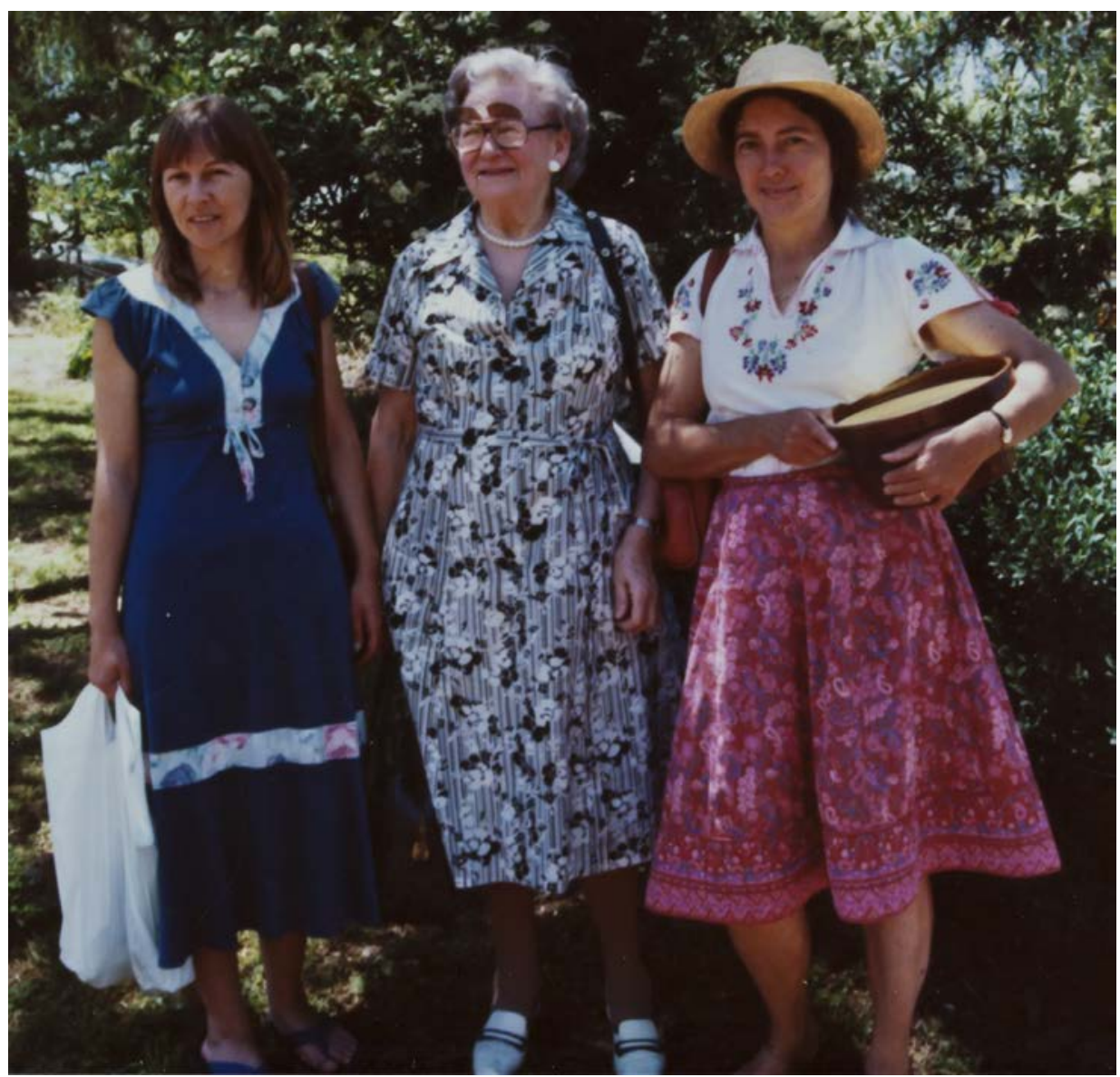

ADB staff, Helen Bankowski, Nan Phillips and Helga Griffin, 1983

By courtesy of Sue Edgar

So, Geoff Serle, at least, saw the $A D B$ as a 'memorial to the mighty dead'. He went on to stress the utilitarian nature of the project:

The $A D B$ is a standard work of reference and a research tool consulted by hundreds of scholars, students and the general public. It has to be as accurate as possible, given the complexity of biographical research; it also has to be readable. It has consolidated knowledge of the most important figures in Australian history and sharply etched in many who previously were shadowy or unknown. Its accumulation of information has, moreover, stimulated research in many areas of Australian history where access was difficult. Above all, the $A D B$ is a national, co-operative enterprise. 
And he showed a pragmatic realisation of the limitations of the exercise:

Yet the $A D B$ does not pretend to be setting up a pantheon of immortals. The most important will be obvious, but the choice of the remainder can only reflect the present state of historians' knowledge. The editorial team claims only to have taken the best advice available and reached the greatest possible measure of agreement; subsequent generations may have other standards of judgment.

So much for any reflection on the theory of prosopography! He did, however, finish his survey with a bit of a boast: 'The ADB prides itself on its blend of elitism and democracy'.

Nairn would not have disagreed with Serle's ruminations on the $A D B$ 's role and purpose. Indeed, I never had any evidence that they differed on anything substantial. The two men certainly got along with each other remarkably amicably. Serle also acknowledged that he and Nairn had inherited a senior editorial staff ... with whom we adopted the most informal, unauthoritarian, collaborative relationship, which increased the very high staff morale and pride in the enterprise. This was primarily Bede's achievement - he was on the spot' ${ }^{13}$

With Serle sojourning in Canberra for only a few days a fortnight, Nairn carried the full administrative load of the project. As Serle's appointment was half-time, he could escape to his 'cave' in Hawthorn and work on his biography of the World War I general Sir John Monash; however, Serle may have understated his role. First, it was a relief to Nairn to be able to consult Serle on the important issues, and he could leave the whole of the Victorian editing and some of the Commonwealth entries in Serle's expert hands, ably assisted by Sally O'Neill and, later, by the accomplished new editorial appointees Di Langmore and Ann Smith. But the constant commuting between Melbourne and Canberra, and residence in a university college, was in itself stressful for Serle.

In setting up and producing most of the volumes covering the floruit period 1891-1939, Nairn and Serle consciously aimed at continuing the style and format established by Douglas Pike. There was some regularisation of practices. For example, the systematic collection of BDM certificates, begun by Nairn, provided access to a certified medical cause of death that had previously not been available. Their friend the medical historian Bryan Gandevia had given occasional advice to Pike for some years. Because the death certificates now provided a cause of death, Gandevia urged that those details should be included in all entries. Serle was concerned that the artistic flow of an article might be affected by this invariable inclusion of technical medical terms. The issue was

13 Bob Carr (ed.), Bede Nairn and Labor History (Leichhardt, NSW: Pluto Press in association with the NSW Branch of the Australian Labor Party, 1991), p. 6. 
discussed with section editors, and by the Editorial Board. ${ }^{14}$ A compromise was reached whereby, where a death certificate was available, a brief cause of death would be provided for people who had died by the age of seventy, but not for those who survived beyond that age. From that time onwards, copies of death certificates for the 'under-seventies' were forwarded to Gandevia, who would then scrawl on the copy a brief interpretation of the chief cause of death. This was edited into the entries. It was a labour of love for Gandevia, and an example of the generous support unobtrusively given to the project by many supporters.

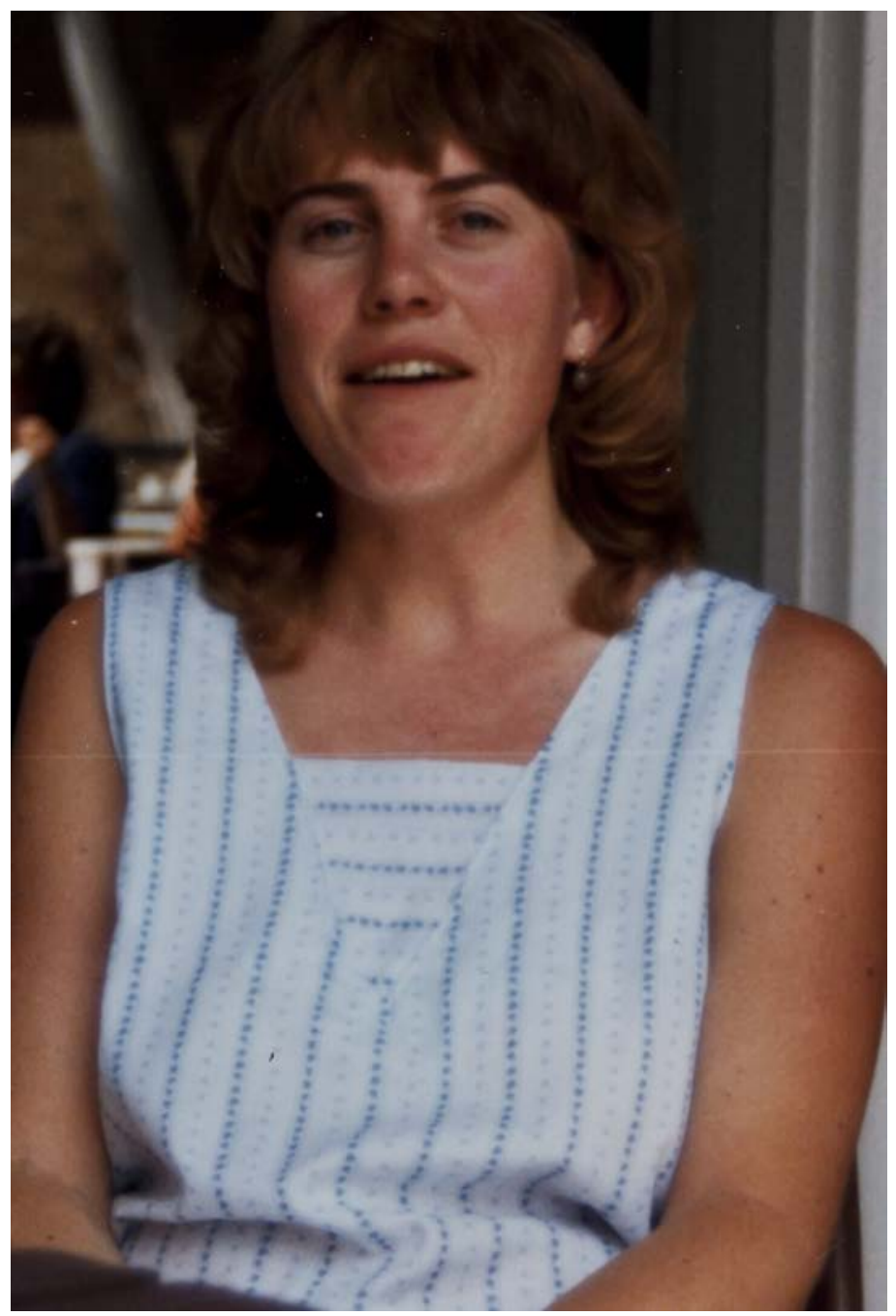

ADB administrative officer Alison Manners, 1980s

By courtesy of Sue Edgar

14 Minutes, $A D B$ Editorial Board meeting (16 May 1977 and 8 November 1979), box 64, ADBA, ANUA. 
Of the volumes Serle edited, he considered Volume 10 to be the most interesting. It included such articles as Stuart Macintyre's on Sir John Latham, Jim Griffin's on Archbishop Daniel Mannix, Jim Davidson's on Dame Nellie Melba and Serle's own masterly assessments of Monash and Sir Keith Murdoch. There were also memorable articles by Nairn on the politician Jim McGowen, and the jockey David 'Darby' Munro. Geoffrey Blainey and Ann Smith co-authored the entry on Essington Lewis, Peter Burgis wrote on Gladys Moncrieff, Tony Cahill on Cardinal P. F. Moran, and Philip Hart and Clem Lloyd on Joseph Lyons. The volume also included what is probably the most notable 'family entry' in the whole $A D B$ - that is, the one on the Lindsays by Bernard Smith. Now that all the entries are wonderfully available in one alphabetical sequence online, and the entries have changed from the floruit to the date of death principle, the flavour of a remarkable cohort of individuals flourishing in a single period is perhaps no longer necessarily possible.

Sally O'Neill has described Serle as 'a wonderful editor, with an elegant but spare style and a real feel for biography and for revealing the subject as a person and not just a list of achievements'. Sue Edgar appreciated his being so well read in literature, as well as in history. Martha Campbell enjoyed his 'surer sense of language', despite the fact that he 'conversed frequently in grunts'.

During his time as general editor, Serle researched and wrote his major biography John Monash (1982) ${ }^{15}$ After their stint as general editors, both Nairn and Serle remained active historians. Serle worked on a study of the Melbourne University vice-chancellor, Sir John Medley (1993), and published a biography of the architect Robin Boyd in 1995. ${ }^{16}$ He died in Melbourne on 27 April 1998, to the last a vital member of the Victorian Working Party. In all, he had written 49 articles for the dictionary, beginning with Charles Ebden in Volume 2 (1967) and ending with Sir John Medley in Volume 15 (2000). Among the most memorable, for me, are those on John Curtin, prime minister, Brian Fitzpatrick, historian, Vance Palmer, writer, Jack Murray, grazier and premier, James Service, businessman and politician, and Bob Croll, author and public servant.

Nairn published his biography of Jack Lang, The 'Big Fella', in 1986 and his last scholarly article in the Journal of the Royal Australian Historical Society in December 2000. ${ }^{17}$ To my horror, he destroyed his personal papers in the 1980s. He died in Canberra on 21 April 2006. Like Serle, he remained active in his working party until the end; although unable to attend meetings, he remained

15 Geoffrey Serle, John Monash: A Biography (Melbourne: Melbourne University Press in association with Monash University, 1982).

16 Geoffrey Serle, Sir John Medley: A Memoir (Carlton, Vic.: Melbourne University Press, 1993); and Robin Boyd: A Life (Carlton South, Vic.: Miegunyah Press, 1995).

17 Bede Nairn, The Big Fella: Jack Lang and the Australian Labor Party 1891-1949 (Carlton, Vic.: Melbourne University Press, 1995); and 'The Governor, the Bushranger and the Premier', Journal of the Royal Australian Historical Society, 86, part 2 (December 2000), p. 114. 
in close contact with its deliberations through correspondence. Among the most notable of his $80 A D B$ entries, apart from those I have already mentioned, are those on politicians Sir John Robertson, Jack Lang, Jack Beasley and Chris Watson; on the trade unionist Frank Dickson; and on the cricketers Archie Jackson and Victor Trumper. His article on Clive Churchill, footballer, was his last: it appeared in Volume 17, after his death.

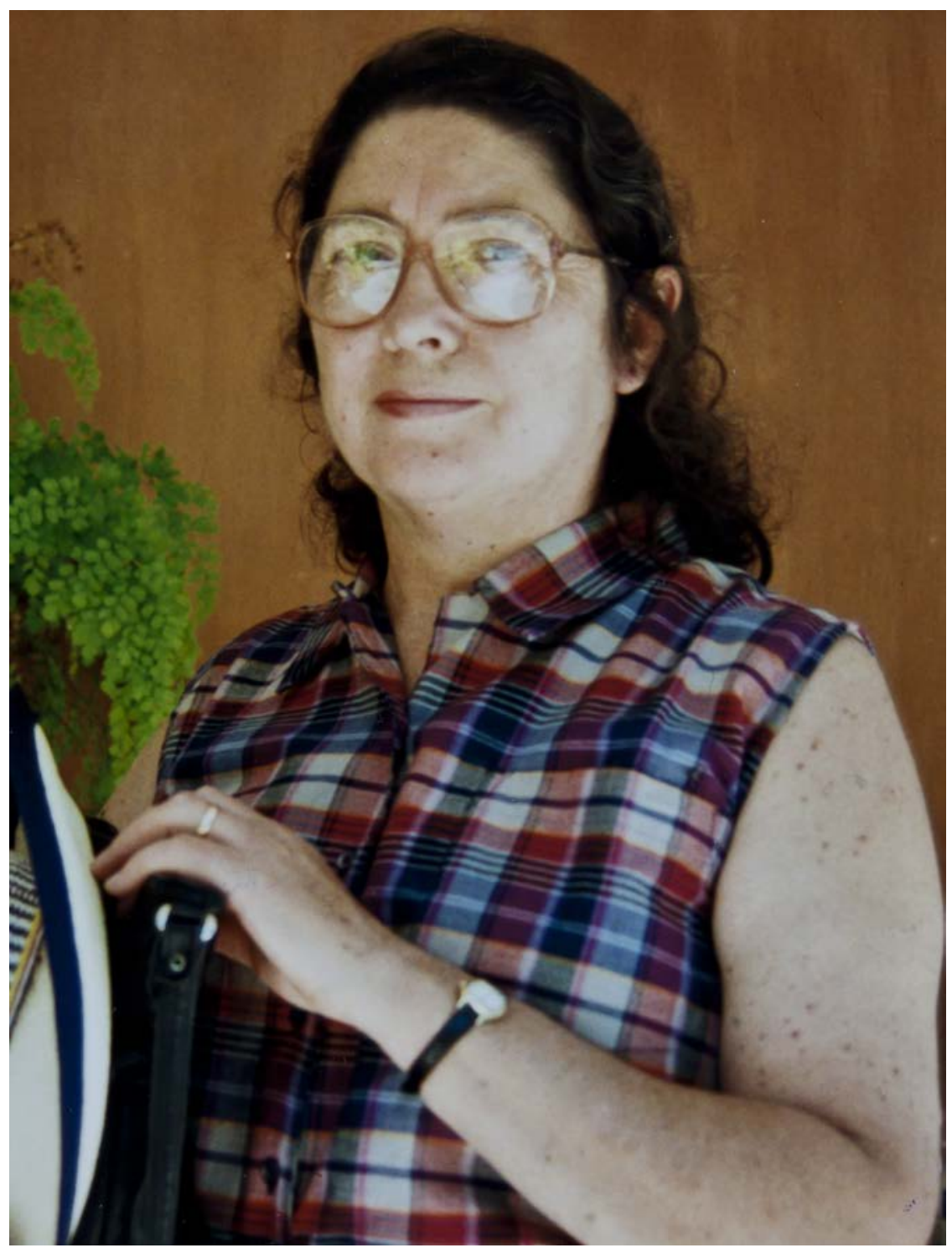

Helga Griffin was the $A D B$ 's bibliographer, 1979-98. She also edited hundreds of $A D B$ entries

By courtesy of Sue Edgar, 1980s 


\section{'[Their] glory was [they] had such friends'}

This chapter has emphasised the individual achievements of the second and third general editors. The essential point in their leadership of the $A D B$ was, however, that they were team men. In this they were supported by outstanding Editorial Board chairmen Ken Inglis and acting chair Alan Barnard. A crucial element in the organisation for Volumes 7-11 was the continuous consultation between the general editors and the five section editors: Geoff Bolton, Ken Cable, Bob O'Neill, John Poynter and Heather Radi. Nairn and Serle relied heavily on the enthusiasm, expertise and wisdom of these historians, who gave their time generously, as did the dozens of members of the working parties and their chairmen, such as Russell Doust, Denis Murphy, Ross Johnston, John Playford, Michael Roe, Alec Hill and Wendy Birman. In addition, both Nairn and Serle had strong connections with their extraordinary team of contributors - thousands of men and women who might sometimes protest about too vigorous editing but retained a remarkable affection for and loyalty to the $A D B$.

In achieving their punishing schedule-five volumes published within 12 years - Nairn and Serle were supported by their dedicated staff at HQ. Apart from those already mentioned there were the expert researchers, such as Merrilyn Lincoln, Hilary Kent, Margaret Steven, Helga Griffin, Gillian Fulloon, Jean Fielding, Sheila Tilse and Alan Fewster, each of whom deserves much more recognition than I have time to give them here. The same goes for the stalwart administrative assistance provided to Nairn and Serle by Dorothy Smith, Norma Gregson, Marion Consandine, Frances Dinnerville, Edna Kauffman, Ivy Meere and too many others to mention by name. The truth is that the finest achievement of Bede Nairn and Geoff Serle was that they nurtured and expanded the $A D B$ 's relationship with the thousands of individuals involved in the enterprise. General editors are indeed important in the $A D B$ story, but the essence of the project is that it is a mighty collaborative effort.

Dr Christopher Cunneen was a Research Fellow (1974-82) and deputy general editor (1982-96) of the ADB. He has been a member of the NSW Working Party since 1975 and of the Editorial Board since 2011. 


\section{Profile}

\section{Chris Cunneen (b. 1940)}

Impressed by Christopher Cunneen's $\mathrm{PhD}$ thesis on the role of the governorgeneral in Australia (ANU, 1973), Bede Nairn recruited him to the $A D B$ as a research fellow. In 1982 Cunneen was appointed deputy general editor. Under Nairn and Geoffrey Serle's joint editorship, he increasingly performed most of the day-to-day management of the project, including allocation of duties to research staff, liaison with working parties and supervision of the office. He also assisted the general editor in editing entries and in preparing the manuscript for publication. As Serle noted, 'sticking to the editorial grind' meant that there was little time for Cunneen to pursue his own research interests and he was overlooked for the position of general editor when it became vacant in 1987. He then served as a loyal deputy to the successful applicant, John Ritchie. In 1996 he took a voluntary redundancy and moved to Sydney where he became an honorary research fellow at Macquarie University. His involvement in the $A D B$ continued: he had been a key member of the NSW Working Party since 1975 and remains so to this day. He led the team that produced the supplement volume in 2005 and joined the Editorial Board in 2011. He has written $77 A D B$ entries.

Sources: Christopher Cunneen, personal file, $\mathrm{NCB} / A D B$ files. Chris Cunneen, Suzanne Edgar and Darryl Bennet, "Solers and heelers of paragraphs": Editing the Australian Dictionary of Biography', in Iain McCalman, with Jodi Parvey and Misty Cork (eds), National Biographies and National Identity (Canberra: Humanities Research Centre, 1996), pp. 149-61. 
The ADB's Story

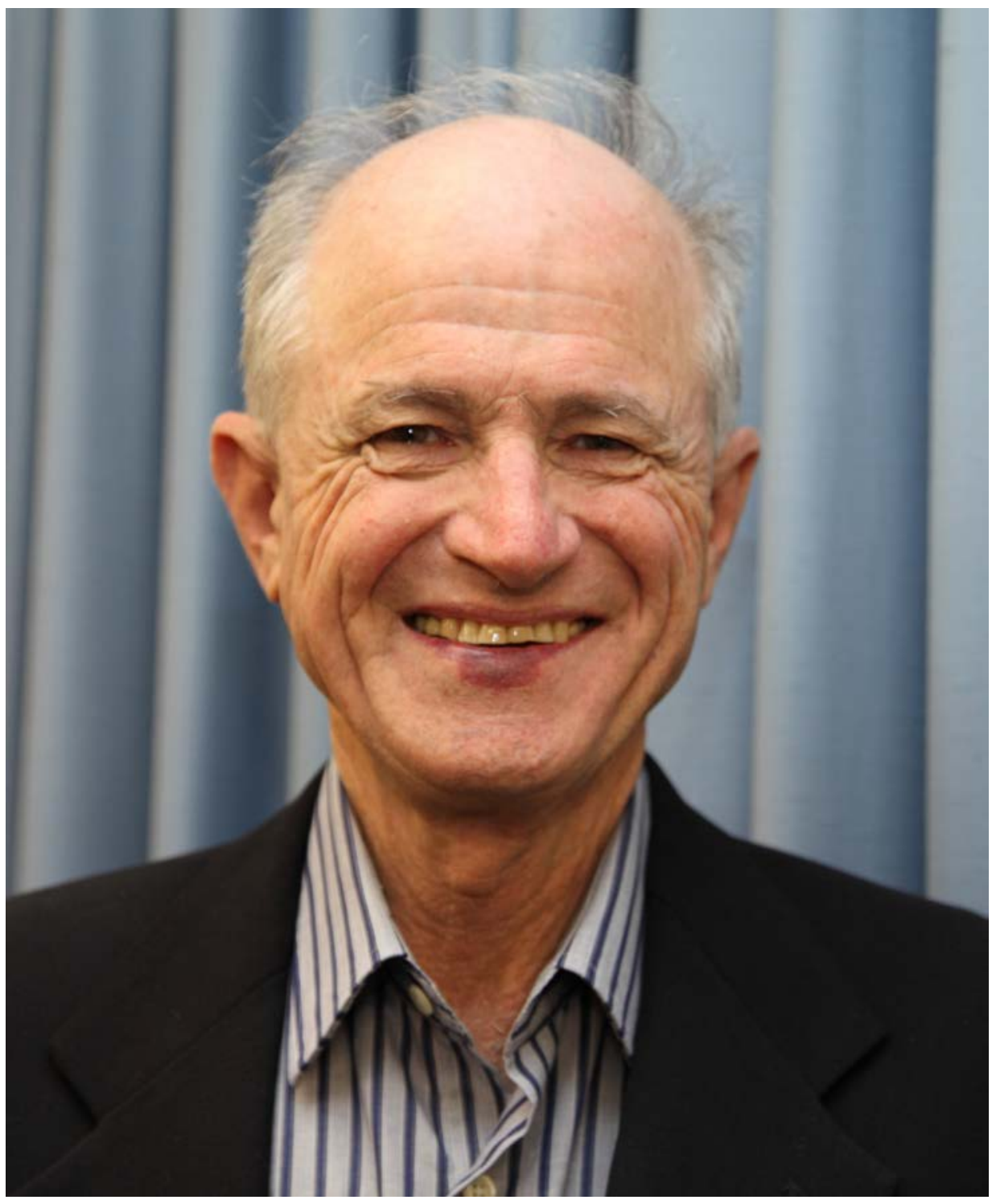

Chris Cunneen, 2012

Photographer: Brian Wimborne, $A D B$ archives 


\section{Profile}

\section{Bryan Gandevia (1925-2006)}

Bryan Gandevia, a respiratory medicine specialist and medical historian, was an $A D B$ author. In 1977 the Editorial Board decided to include cause of death for those subjects who had died under the age of seventy. When research editors found it difficult to interpret the information provided on death certificates, Gandevia's advice was sought. He proposed that the $A D B$ send him copies of the death certificates as they came to hand and he would 'summarise them and develop a classification'. This involved him in a 20 -year project with the $A D B$, in which he wrote down the major cause of death on each certificate and returned them to the office. One of the 'unsung heroes' of the $A D B$, Gandevia considered it a 'privilege to be able to assist in such a magnificent national project'. He wrote widely on the history and bibliography of Australian health and welfare measures and helped to found in 1986 the Australian Society of the History of Medicine. He also served on the Australian War Memorial (AWM) Board of Trustees and subsequently as a member of the AWM Council (1967-88).

Sources: Brian Gandevia, correspondence, 1960-92, including Bryan Gandevia to A. G. Serle (13 June 1986), box 136, Q31, ADBA, ANUA. Geoffrey Field, 'Bryan H. Gandevia Obituary', Thoracic Society News, 16, no. 4 (December 2006), p. 81. Brenda Heagney, 'Bryan Gandevia Obituary', Health and History, 8 , no. 2 (2006), pp. 186-91. 


\section{Profiles}

\section{Margaret Steven (b. 1933) and Heather Radi (b. 1929)}

Margaret Steven, who graduated with a PhD in history from ANU in 1963 and had written a number of books on colonial and imperial history, joined the $A D B$ in 1978 as a research editor, responsible for the Commonwealth desk. She remained until 1996. Heather Radi, a lecturer in history at the University of Sydney, was appointed in 1975 to both the NSW Working Party and the Editorial Board. A feminist with an interest in women's biography, she was the first woman member of the board and strongly supportive of its aim to increase the proportion of entries on women 'to 10 per cent or more'. Both Steven and Radi were heavily involved in bicentennial history projects: Steven advised on and researched a special exhibition in London on the British role in the 'discovery' of Australia based on the collections of the British Museum of Natural History; Radi edited 200 Australian Women: A Redress Anthology (1988). She retired from the Editorial Board in 1994 but remained on the NSW Working Party until 2005. Steven has contributed 24 articles and Radi 37, on a wide range of subjects, to the $A D B$.

Sources: Margaret J. E. Steven, personal file, NCB/ADB files. ANU Reporter (28 October 1988), p. 5. Heather Radi to Geoffrey Serle (20 May 1987), box 142, Q31, ADBA, ANUA. Heather Radi (ed.), 200 Australian Women: A Redress Anthology (Sydney: Women's Redress Press, 1988). 


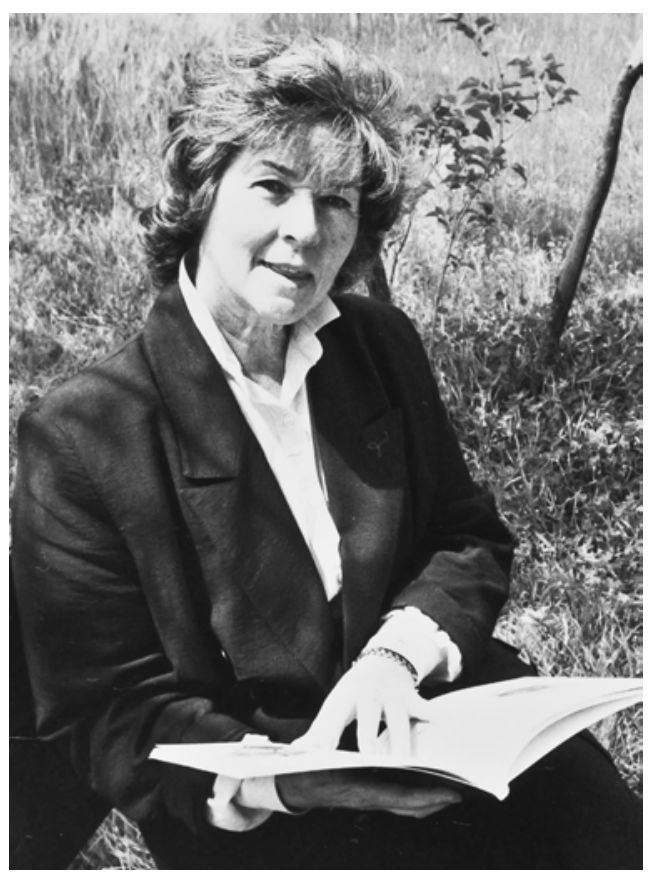

Margaret Steven, 1988

ANU Archives, ANUA225-1184

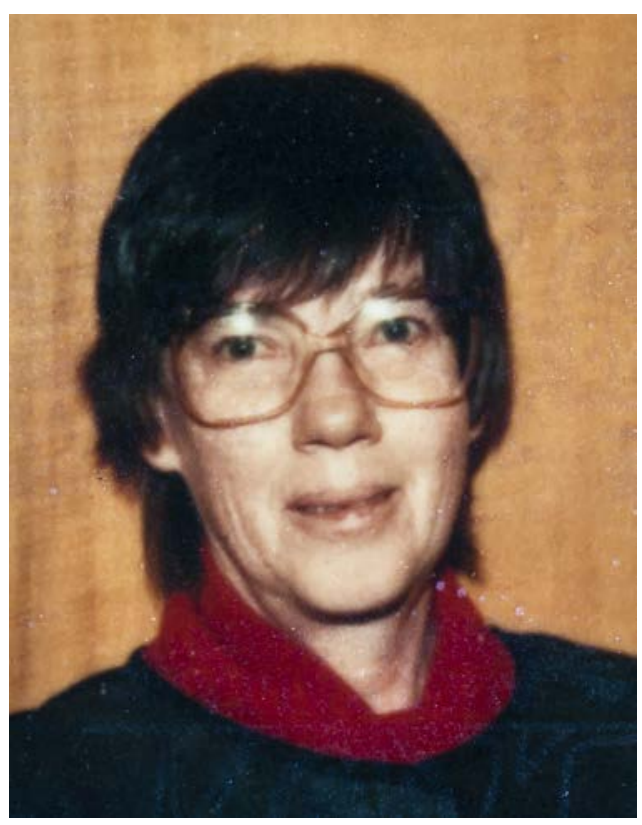

Heather Radi, 1980s

By courtesy of Heather Radi 